\title{
An Online Professional Learning Program for Supporting Vocational School Teachers' Online Classroom via WhatsApp Group
}

\author{
Iyen Nurlaelawati*, Ika Lestari Damayanti, Jeani Shinta Rahayu \\ English Education Department, Universitas Pendidikan Indonesia \\ *Corresponding author. Email: iyenn@upi.edu
}

\begin{abstract}
This descriptive study reports an online professional learning program of vocational schoolteachers aiming to support the teachers' pedagogic practice in using WhatsApp groups for their online classrooms. Specifically, the study examined the teachers' learning experiences during the training and their lesson plans in deploying affordances of WhatsApp platform to help their students learn. This study involved 90 teachers in a public vocational school in West Java Province, Indonesia. The data were collected from the observation of a one-day training, WhatsApp classroom simulation on teaching reading, the teachers' responses on the training, and the teachers' lesson plans. The findings demonstrated the teachers' increased awareness about the importance of planning clear and specific instructions to their students in WhatsApp classrooms. The teachers' lesson plans indicated the incorporation of several features, such as voice notes and emojis, to ignite positive interactions between the teachers and their students. The limitation of the study is that there were no simulations with real students to portray the authentic WhatsApp interactions with students. Thus, based on the findings and the limitations, it is recommended to observe teachers in conducting their online classes with their students.
\end{abstract}

\section{Keywords: Classroom interactions, Professional learning, Scaffolding, Vocational school, WhatsApp}

\section{INTRODUCTION}

The global COVID-19 pandemic has affected the ways of lives of so many people around the globe, including teachers and students. As part of the procedures to control the spread of the virus, schools are forced to shift their face-to-face teaching and learning processes to online platforms. Such a swift change entails two-faced implications: benefits of the versatility of online platforms for both teachers and students, and challenges of mastering the skills to utilize the platforms for better learning outcomes.

An online classroom with its characteristics can challenge the success of the teaching and learning process. As reported in a number of studies, WhatsApp, Telegram, Google Classroom, and Edmodo are some of the platforms that are considered easy to use for the teaching and learning processes (Bere, 2012; Church \& de Oliveira, 2013; Rambe \& Bere, 2013; Yeboah \& Ewur, 2014). However, many teachers are not ready to design online learning interactions that can effectively engage their students to the lessons (Rambe \& Bere, 2013; Sharples et al., 2012).
The new nuanced learning environment in WhatsApp platform has also been a concern of teachers in a public vocational school in West Java, Indonesia. These teachers were worried that morphing from their 'conventional' into remote online learning classrooms may bring potential threats to their students' learning outcomes. It is against this background that the study reported in this paper is concerned with an investigation into ways of supporting teachers to conduct their online classrooms through an online professional learning program. Specifically, the study sets out to examine the teachers' learning experiences during the training and their lesson plans in deploying affordances of the WhatsApp platform to help their students learn.

\section{LITERATURE REVIEW}

\subsection{WhatsApp as a learning platform}

A large number of studies investigated the use of social media for teacher professional learning (Bissessar, 2014; Bledsoe \& Pilgrim, 2016; Krutka \& Carpenter, 2016; Prestridge, 2018). The popularity of social media, such as Facebook and WhatsApp, as an 
alternative platform for teacher professional development programs, owes to their user-friendly affordances for daily interactions. It is reported that for teaching and learning purposes, social media are used to facilitate teachers' and students' discussions, share digital materials, administer quizzes, and give feedback.

Of the available online learning applications, WhatsApp gains more educators' attention in developing countries, including Indonesia (Gon \& Rawekar, 2017; La Hanisi, Risdiany, Dwi Utami, \& Sulisworo, 2018). The application offers its users versatile features with low-cost technology and accessibility from mobile devices, which are already part of daily necessities for interacting with family and friends. For example, users can post-verbal or multimedia messages followed up by extended conversations among its users. Damayanti and Sibarani (forthcoming) reported that WhatsApp is widely used for online classrooms in Indonesia. Through WhatsApp, teachers and students are able to send messages both personally and in-group, and send multimedia messages like photos, videos, audio files along with text messages.

Another recent study by Motteram, Dawson, and AlMasri (2020) on the use of WhatsApp group in classroom activities highlights the strengths of the WhatsApp group for professional learning. The results indicated that WhatsApp group discussion facilitated the participant teachers to share and discuss issues related to their contexts in teaching English language. Through such discussions, the teachers in this study demonstrated their increased knowledge about English language and how to transform their knowledge into the development of teaching materials for their students.

Despite its versatility and affordability, the use of WhatsApp for online classroom is not without its drawbacks. Several studies conducted in Indonesia exploring the use of WhatsApp for the online classrooms indicated that technical problems and students' lack of participation in the lesson are some of the most challenging aspects. Technical problems reported include compatibility issues of operating systems, limited access to smartphones, and internet connectivity. The students' out-of-topic discussions and the occurrence of message flooding are identified issues related to WhatsApp classroom interactions (Damayanti \& Sibarani, forthcoming; Klein, Junior, Barbosa, \& Baldasso, 2018; Maphosa, Dube, \& Jita, 2020).

While technical problems such as internet connectivity are somehow beyond the teachers' control, making classroom interactions engaging is one of the teachers' manageable issues. In a face-to-face classroom, teacher-student interactions occur in a hereand-now context. Both teachers and students share the same space and time, in which teachers' instructions can be supported by shared physical environments and any potential misunderstandings can be clarified immediately. The online WhatsApp classrooms, however, set forth a different arena of learning situations. The communication flow tends to be linear with learning environments that may vary from one student to another.

\subsection{Scaffolding in online learning}

Wood, Brunner, and Ross (1976) proposed the notion of scaffolding to help teachers to support their students' learning. This concept is in line with Vygotsky's Zone of proximal development which highlights the gap between what learners can do alone and what they can do in collaboration with more skilled others. Hence, teachers are the more skilled others in the classroom.

In a classroom setting, Hammond and Gibbons (2005) categorize two types of scaffolding; designed-in and instructional scaffolding. Designed-in scaffolding is when the decision for lesson sequences has been planned. The instructional one is when the support occurs spontaneously, such as teachers' talk, which is the focus of this study.

In relation to designed-in scaffolding, Rose and Martin (2012) developed a teaching/learning cycle that begins by establishing common ground with students ('shared context of experience'), and then making meaning together with the students ('guidance through interaction'), before asking students to do work on their own (the learning task). These principles are translated into different teaching procedures involving a learning cycle.

At the centre of a learning cycle is a learning task, completed only by the learners and typically focused and evaluated by a teacher (Rose \& Martin, 2012). Three main elements of a learning cycle are Focus, Task, and Evaluate. This interaction pattern resembles the Initiation-Response-Evaluation (I-R-E) exchange pattern, typically found in most classroom discourse. With such a pattern, classroom interaction tends to engage top students who can complete the task. To ensure that all students, including the low achievers, participate in the interaction, Rose and Martin (2012) extended this typical pattern by adding Prepare and Elaborate moves. Teachers may prepare the students before asking them to complete a task by helping students recognize meanings of wording in a text and elaborate the meanings by providing more examples in different contexts.

In order to design a teaching and learning cycle that potentially impacts students' learning outcomes. The pedagogic register includes pedagogic relations, pedagogical activities, and pedagogic modalities. Pedagogic relations between teachers and students should embrace equality, that is each student receives equal attention from the teacher to support their 
learning. Pedagogic activities are concerned with sequences of activities that support students to accomplish the desired outcome. This should be designed by preparing and focusing the students on the task they must complete. Pedagogic modalities include choices of using spoken, written visual and manual practice, to support students' learning process.

\section{METHOD}

This qualitative study investigated a one-day online training, involving 90 teachers of various subjects in a public vocational school in West Java province, Indonesia. The purpose of the training was to support the teachers to provide interactive teaching and learning of literacy via WhatsApp group. Two of the authors were the trainers in the professional learning program. The training used a variety of media including Zoom meeting, WhatsApp Group, Mentimeter, Wheel-ofname, and Padlet. The training lasted for eight hours. The training activities included discussion on conceptual ideas, simulation of an online class via WhatsApp group, and reflection on the simulation, followed up by lesson planning and reflection on the training program.

For the purpose of the study, three data sets were used as data collection. The first was the transcript of the WAG simulation that was first parsed on lesson stages. Teacher talk in each stage was also identified in terms of its pedagogic activities, relations, and modalities. The second data set was the participant teachers' lesson plans that were also analysed based on the pedagogic register. Then, the last was the participant teachers' reflection on the online training that was analysed based on the topics mostly brought up by the participant teachers.

\section{FINDINGS AND DISCUSSION}

\subsection{WhatsApp Group teaching simulation}

A one-hour simulation of an online class via WhatsApp group involved the teacher participants playing roles as students of vocational school and one of the trainers acted as a teacher. This simulation aims to provide teachers with learning experiences of how WhatsApp classroom could be conducted. The stages observed from the simulation include orientation where the teacher set up the class and check students' attendance, followed by the lesson stages that consisted of pre-reading, whilst-reading and post-reading. Table 1 shows the stage of preparing the class.

In setting up the class, the teacher introduced classroom rules using various features available in WhatsApp such as video sharing, image, and emoji. This early stage aims to invite students' attention and engage them in the lesson by requiring them to take some action, for example opening the video link and watching it. The teacher also used a time frame for the students to complete the task. As a result, it can be seen that all students responded to the instruction effectively where all students simply typed emojis to indicate their presence (See student actions).

\subsubsection{Pre Reading}

Once the rules had been established, the teacher elicited the students' background knowledge about "batik". Interestingly, the teacher also used various learning modalities not only what was available in the WhatsApp platform but also students' home environment. Then, the teacher started to share a link to a text that the students need to access for getting the information related to batik. Another point that is worth noticing is the way the teacher instructed to get the lesson going. In every instruction, the teacher used a time frame. The pre-reading activities can be seen in table 2 .

Table 1. Preparing the class

\begin{tabular}{lll}
\hline \multicolumn{1}{c}{ Teacher talks } & \multicolumn{1}{c}{ Activities } & \multicolumn{1}{c}{ Relations } \\
\hline $\begin{array}{l}\text { To start today's lesson, please watch the video in the } \\
\text { following link. }\end{array}$ & Greetings & Students' action \\
& $\begin{array}{l}\text { Classroom } \\
\text { management }\end{array}$ & Video \\
Classroom & management & Students' action \\
Read the following classroom rules. & Classroom \\
If you understand the rules, type this emoji $\square$ in 5 minutes. & Students' action \\
It also shows you are present. & Time frame & Emojis
\end{tabular}


Table 2. Pre-reading activities

\begin{tabular}{llll}
\hline Teacher talks & Activities & Relations & Modalities \\
\hline $\begin{array}{l}\text { Let's start the lesson. What do you know about batik? In } \\
5 \text { minutes, type what you know about batik. }\end{array}$ & $\begin{array}{l}\text { Prepare } \\
\text { Classroom management: } \\
\text { time frame }\end{array}$ & $\begin{array}{l}\text { Students' } \\
\text { knowledge }\end{array}$ & Chat box \\
$\begin{array}{l}\text { Now, in the next } 5 \text { minutes, identify at least three } \\
\text { products made of batik that you can find around you. }\end{array}$ & $\begin{array}{l}\text { Prepare } \\
\text { Classroom management: } \\
\text { time frame }\end{array}$ & $\begin{array}{l}\text { Students' } \\
\text { knowledge }\end{array}$ & $\begin{array}{l}\text { Students' } \\
\text { home } \\
\text { environment }\end{array}$ \\
$\begin{array}{l}\text { Well, let's learn more about batik. Read the following } \\
\text { text for about } 3 \text { minutes. While reading, identify batik } \\
\text { based on the type of its textile. }\end{array}$ & $\begin{array}{l}\text { Prepare } \\
\text { Classroom management: } \\
\text { time frame }\end{array}$ & & \\
\hline
\end{tabular}

\subsubsection{While reading}

The while-reading activities emphasized the discussion of batik cloth, how it is different from other clothes. In this part of the lesson, the activities invited the students' focus on completing several activities such as reading a text and completing a table based on the text. As the class got into the main lesson, the instructions given by the teacher were getting sophisticated but here the teacher presented the instructions in a smaller chunk and more specific with step-by-step action, including the number of students who were expected to participate. The while-reading activities can be seen in table 3 .

\subsubsection{Student Action}

Student actions involved students' responses towards the instructions. Beginning the lesson, the students responded to the instruction on reading classroom rules. Their action was sending emojis to signify their understanding on the rules and their presence in the lesson as seen in figure 1.

Table 3. While-reading activities

\begin{tabular}{|c|c|c|c|}
\hline Teacher talks & Activities & Relations & Modalities \\
\hline $\begin{array}{l}\text { Here's the link: http://www.medogh.com/blog/artikel- } \\
\text { batik/perbedaan-kain-batik-dan-kain-tekstil-bermotif-batik/ }\end{array}$ & Focus & Shared text & link \\
\hline $\begin{array}{l}\text { Next, complete the table. } \\
\text { 1. copy the table on your notebook. } \\
\text { 2. complete the table with information from the text. } \\
\text { 3. take a picture of your table and share in this wag }\end{array}$ & $\begin{array}{l}\text { Focus: } \\
\text { Prepare on the } \\
\text { task instruction }\end{array}$ & $\begin{array}{l}\text { Students' action: } \\
\text { students' taking picture } \\
\text { and completing a table. }\end{array}$ & $\begin{array}{l}\text { Chat box, a } \\
\text { table template }\end{array}$ \\
\hline $\begin{array}{l}\text { Briliant! We already had more than } 10 \text { students sending the } \\
\text { task. Now, you know the characteristics of batik and batik- } \\
\text { like textiles. }\end{array}$ & Affirm & & \\
\hline $\begin{array}{l}\text { I will explain again and add more information. Listen to the } \\
\text { voice note and add information on your table. }\end{array}$ & Elaborate & teacher knowledge & $\begin{array}{l}\text { Shared text: } \\
\text { table, voice } \\
\text { note }\end{array}$ \\
\hline
\end{tabular}




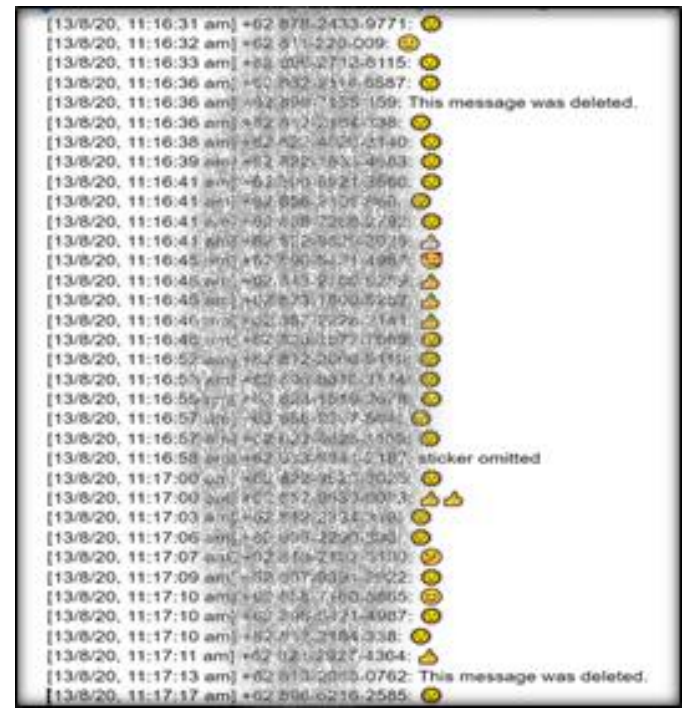

Figure 1 Student' emoji

The other action displayed here is the relevance of the students' responses towards the instructions as seen in figure 2. Students' talks in yellow are those irrelevant to the task while the green is the one to the task. With specific instructions, the students could respond successfully to the task, while some students tried to divert from the lesson. However, the teacher ignored these irrelevant comments. Later in the lesson, the students were more cooperative in responding to the task as the 'silly' comments were consistently being ignored by the teacher. Ignoring the irrelevant comment to the lesson was deliberately done by the teacher to avoid unnecessary thread of conversation that often happens in such online platforms.

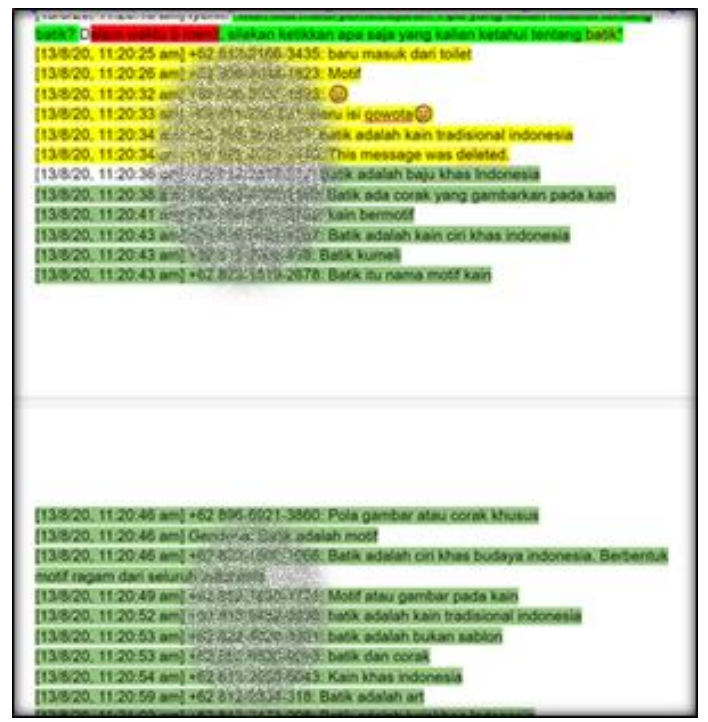

Figure 2 Students' responses towards instructions

\subsection{The teacher participants' lesson plans}

The analysis of the second data set focused on the teacher participants' lesson plans and evaluated their conformity with the lesson plan format discussed in the training. Of the 30 groups in the training, three groups did not submit their lesson plans, nine groups constructed their lesson plans using the given format, and eighteen groups submitted their lesson plans without using the format. In this paper, one lesson developed based on the format (hereafter referred to as Lesson One) and a lesson that was designed without following the format (Lesson Two) are examined and discussed in detail.

The analysis of Lesson One (See appendix) showed that the plan conformed to the model plan introduced earlier. Lesson One was Indonesian History subject for Grade 10 students. The objective of the lesson was reading to identify different theories of the advent of Hinduism and Buddhism to Indonesia. The lesson plan comprised the activities that were staged into preparation, pre-activity, while activity, and post activity. In each stage, the lesson plan presented teacher talk, activities, interaction, and media.

The preparation stage was used to remind the students of the time of the subject on the scheduled day. The lesson started in the pre-activity stage by showing several routines that usually take place in a face-to-face classroom such as greeting, introduction to the days' topic, class rules, a roll call, and exploration of students' prior knowledge. Teacher talk could be identified in the opening leading to the topic. However, when it came to the topic, the lesson plan did not show any statements; rather, teachers' activities of sending pictures of temples for the students to observe and expecting students' response in a given time. All of the activities in the preparation and pre-activity stages were intended for preparing the students for the lesson, unless the last activity in the pre-activity stage that is expecting the students to observe the pictures and to reply to the task. In the last two stages, the sample lesson plan in table 4 showed the focus of two main tasks students had to complete, through two kinds of mode such as attachment and chat box, including reading a text and creating a mind map based on the text. Teacher talk was not also identifiable in this sample lesson plan. 
Table 4. A sample lesson plan of Lesson Two

\begin{tabular}{|c|c|c|c|}
\hline Teacher talk & $\begin{array}{l}\text { Pedagogic } \\
\text { activity }\end{array}$ & $\begin{array}{l}\text { Pedagogic } \\
\text { relation }\end{array}$ & $\begin{array}{l}\text { Pedagogic } \\
\text { modalities }\end{array}$ \\
\hline "Assalamualaikum. How are you today students?" & Greeting & $\begin{array}{l}\text { Teacher- } \\
\text { students }\end{array}$ & Chat box(?) \\
\hline "Today's subject in PE is armstand and bridge position." & Prepare & Teacher & Chat box(?) \\
\hline $\begin{array}{l}\text { "I have shared the pictures of how to do the positions from the } \\
\text { beginning to the end." }\end{array}$ & Focus & Teacher & Pictures(?) \\
\hline "Write your answers and photograph the result." & Focus & Teacher & Chat box(?) \\
\hline
\end{tabular}

Lesson Two was taken from the subject Physical Education without specific intended class and objective mentioned. The lesson plan consisted of only teacher talk. Based on the pedagogic register analysis, as depicted in table 3 , the teacher talk prepares and focuses the students to the task with the use of chat box and attachment features to send pictures. The relation centered in the teacher as the task provider, in which students were likely treated as passive participants, not involved in the lesson.

\subsection{The teacher participants' responses}

The last data set was the teacher participants' responses towards the training, especially the simulation. The teacher mentioned that the training supported them to be more open towards the use of WhatsApp Group application as an online class. They reported that before the training, they had doubted to have effective instructions in their WhatsApp class. It seemed to them that WhatsApp application was the only alternative they could use so far with their students for its accessibility and affordability. Despite their onset hesitancy, experiencing the online learning via WhatsApp Group simulation made them realize that the application could be explored in terms of its features with effective instructions. They identified that they could still have two ways of communication with their students. It was noted as important for them to provide examples of how to do the tasks and to assign not many tasks at once. They were also enthusiastic to use other modes in their instructions such as Padlet and Mentimeter (two applications used in the conceptual, lesson planning, and reflection sessions).

Despite the positive response, the participant teachers also shared that the simulation would not help much in certain subjects such as Math and subjects that require practicum. In real life, they had more parallel classes, so they would find it overwhelming to design teacher talk, activities, and media as suggested in the simulation. They also felt that the simulation with peer teachers tended to be all under control and unrealistic. In actual classrooms, they found that students tended to flood them with unnecessary chats, which did not happen in the simulation. For future training, they wished to participate in a simulation with real students instead of peer teachers so that they could learn how trainers handled the unexpected situations.

\section{DISCUSSION}

The analyses of the data sets have provided insights into the teacher participants' learning experiences in an online training. The finding indicates that the simulation provided a participatory activity that helped the participant teachers to better understand how scaffolding was provided in WhatsApp class to support students' learning interactively. The interaction was built starting from the first activity through sending an emoji showing the students' presence in the lesson. Later on the instructions emphasized on "prepare" prior to focusing the students to the task. Rose and Martin (2012) point out the importance of preparing the students before focusing them to the task. They mention “... teaching means preparing learners for each learning task, and then handing control to the learner to do the task themselves." (p. 8). Showing examples may mean a strategy to prepare students to complete the task as well. The lesson in the simulation had proven the relatively smoothness of the task completion that may be assumed due to the support of preparation prior to focus.

This success of simulation did not just happen, rather the instructions were planned in terms of pedagogic register, activities, relations, and modalities. Hammond and Gibbons (2005) suggest the designed-in and instructional scaffolding. The first refers to the planned activities, and the latter is spontaneous support in the classroom. They include teacher talk as an interactional scaffolding because it happens spontaneously in the classroom. Based on the findings in the present study, we argue that teacher talk in WhatsApp class should be designed before instruction starts in an online classroom. Teacher talk (pedagogic relations) becomes a priority, along with activities development (pedagogic activities), to avoid misunderstanding in task completion, supported by the features afforded by WhatsApp Group application (pedagogic modalities). 
The simulation also exposed the affordances of WhatsApp Group application to support students' learning. Based on the findings in the simulation, WhatsApp application had provided benefits for teaching and learning, especially in this pandemic situation, as mentioned by Bere (2012), Maphosa, et al. (2020), Motteram, et al. (2020), and Sharples et al. (2012), in terms of students' attitudes, behavioural intention, and the platform's usefulness.

On the other hand, it is a call for trainings to give more support to teachers to develop the lesson, especially to increase their awareness of planning teacher talk. The data of lesson plans show that teachers' attention was merely to deliver the lesson by giving instructions to the main task, paying less attention to build the students' interest and prior knowledge and to make use of the potential features of the used platform. According to Gon and Rawekar (2017), teachers' role to provide meaningful teaching is also afforded by the application, besides its high accessibility for both teachers and students.

\section{CONCLUSION}

This study presented the need to provide simulation with clear context after discussing the concept intended in training, as well as the need to use an online application to monitor and support teachers' collaboration in the training. The findings also show that the online professional learning program held in this study provided the participants opportunity to reflect on their learning experiences. Professional learning program needs to include participatory activities such as simulation in addition to conceptual discussions. As the online learning is conducted in WhatsApp group, this study highlights the use of specific instruction to deliver various features in the online platform.

This study involved a one-day training of professional learning for vocational teachers that may not represent general results. Due to limited time of training and distant learning, teacher participants' activities in developing lesson plans could not be observed optimally. Thus, for further study it is recommended that such training be implemented in using more various applications to guide teachers in developing effective lessons.

\section{REFERENCES}

Bere, A. (2012). A comparative study of student experiences of ubiquitous learning via mobile devices and learner management systems at a South African university. In P. A. van Brakel (Ed.), Proceedings of 14th Annual conference on world wide web application. Cape Town.

Bissessar, C. S. (2014). Facebook as an informal teacher professional development tool. Australian Journal of Teacher Education, 39(2).

Bledsoe, C., \& Pilgrim, J. (2016). Creating "Spaces" for professional development: Education organizations' use of Facebook. Social Media and Society, 5, 89110.

Church, K., \& de Oliveira. R. (2013). What's up with WhatsApp? Comparing mobile instant messaging behaviors with traditional SMS. Proceedings of the 15th international conference on Human-computer interaction with mobile devices and services (MobileHCI '13) (pp. 352-361). Munich, Germany: ACM.

Damayanti, I. D., \& Sibarani, B. L. (forthcoming). WhatsApp with preservice teacher learning experiences in the midst of COVID-19 pandemic. Language, Education, and Policy for the Changing Society: Contemporary theory and research. Bandung: UPI Press

Gon, S., \& Rawekar, A. (2017). Effectivity of e-learning through Whatsapp as a teaching learning tool. $M V P$ Journal of Medical Sciences, 4(1), 19-25

Hammond, J., \& Gibbons, P. (2005). Putting scaffolding to work: The contribution of scaffolding in articulating ESL education. Prospect, 20(1).

Klein, A. Z., Junior, J. C., Barbosa, J. L., \& Baldasso, L. (2018). The educational affordances of mobile instant messaging (MIM): Results of WhatsApp used in higher education. International Journal of Distance Education Technologies, 16(2), 51-64.

Krutka, D. G., \& Carpenter, J. P. (2016). Participatory learning through social media: How and why social studies educators use Twitter. Contemporary Issues in Technology and Teacher Education, 16(1), 38-59.

La Hanisi, A., Risdiany, R., Dwi Utami, Y., \& Sulisworo, D. (2018). The use of WhatsApp in collaborative learning to improve English teaching and learning process. International Journal of Research Studies in Educational Technology, 7(1), 29-35.

Maphosa, V., Dube, B., \& Jita, T. (2020). A UTAUT evaluation of WhatsApp as a tool for lecture delivery during the COVID-19 lockdown at a Zimbabwean 
university. International Journal of Higher Education, 9(5), 84-93

Motteram, G., Dawson, S., \& Al-Masri, N. (2020). WhatsApp supported language teacher development: A case study in the Zataari refugee camp. Educ Inf Technol, 25, 5731-5751.

Prestridge, S. (2018). Categorising teachers' use of social media for their professional learning: A selfgenerating professional learning paradigm. Computers \& Education. 129. https://doi.org/10.1016/j.compedu.2018.11.003

Rambe, P., \& A. Bere. 2013. Using mobile instant messaging to leverage learner participation and transform pedagogy at a South African University of Technology. British Journal of Educational Technology 44(4), 544-561. http://doi.wiley.com/10.1111/bjet.12057
Rose, D., \& Martin, J. R. (2012). Learning to write, reading to learn: Genre, knowledge and pedagogy in the Sydney School. Sheffield, UK: Equinox Publishing Limited

Sharples, M., Mcandrew, P., Weller, M., Ferguson, R., Fitzgerald, E., Hirst, T., Mor, Y., Gaved, M., \& Whitelock, D. (2012). Innovating pedagogy 2012. Milton Keynes: The Open University.

Wood, D., Bruner, J., \& Ross, G. (1976). The role of tutoring in problem solving. Journal of Child Psychology and Psychiatry, 17, 89-100.

Yeboah, J., \& Ewur, G. D. (2014). The impact of WhatsApp Messenger usage on students' performance in tertiary institutions in Ghana. Journal of Education and Practice, 5(6), 157-1. 


\section{Appendix}

A sample lesson plan of Lesson One

\begin{tabular}{|c|c|c|c|}
\hline Stage & Teacher talk & Activities & Interaction \\
\hline Preparation & $\begin{array}{l}\text { "Assamualaikum (Greeting usually said } \\
\text { by Muslims). } \\
\text { Good morning, everyone. } \\
\text { Don't forget that we have Indonesian } \\
\text { History today. The class will start in } 15 \\
\text { minutes." }\end{array}$ & Prepare: Class & $\begin{array}{l}\text { - } \quad \text { Teacher to } \\
\text { students } \\
\text { - } \quad \text { Students' } \\
\text { response: replying } \\
\text { the greeting } \\
\text { - Students' } \\
\text { response: affirming }\end{array}$ \\
\hline \multirow[t]{5}{*}{ Pre-activity } & $\begin{array}{l}\text { "Assalamualaikum } \mathrm{Wr} . \mathrm{Wb} . \\
\text { How are you? } \\
\text { I hope you all well. } \\
\text { We are in the subject Indonesian } \\
\text { History again today." }\end{array}$ & Prepare: Opening & $\begin{array}{l}\text { - } \quad \text { Teacher to } \\
\text { students } \\
\text { - } \quad \text { Students' } \\
\text { response: replying } \\
\text { the greeting }\end{array}$ \\
\hline & $\begin{array}{l}\text { "Today's topic is about the theories of } \\
\text { the advent of Hinduism and Budhism to } \\
\text { Nusantara (another name of Indonesia } \\
\text { by locals)" }\end{array}$ & $\begin{array}{l}\text { - Prepare: Introducing } \\
\text { the day's topic }\end{array}$ & $\begin{array}{l}\text { - } \\
\text { students }\end{array}$ \\
\hline & $\begin{array}{l}\text { Reciting Bismillah (an Arabic } \\
\text { expression usually used to start the } \\
\text { lesson in the classroom) } \\
\text { "Please don't type unnecessary and } \\
\text { unrelated sentences to the topic. } \\
\text { Don't send the assignment yet until you } \\
\text { are told to do so. } \\
\text { Don't send stickers." }\end{array}$ & Prepare: class rules & $\begin{array}{l}\text { - } \\
\text { students }\end{array}$ \\
\hline & $\begin{array}{l}\text { "Your presence in the class is shown by } \\
\text { sending an emoji of "thumb up" in five } \\
\text { minutes. " }\end{array}$ & Prepare: Taking a roll & $\begin{array}{lr}\text { - } & \text { Teacher to } \\
\text { students } & \\
\text { - } & \text { Students' } \\
\text { response: } & \text { sending } \\
\text { the emoji } & \end{array}$ \\
\hline & $\begin{array}{l}\text { Teacher sends pictures of temples } \\
\text { Teacher gives } 10 \text { minutes for the } \\
\text { students to write their observation on } \\
\text { the pictures. }\end{array}$ & $\begin{array}{l}\text { - } \quad \text { Focus: Exploring } \\
\text { students' prior knowledge } \\
\text { about the origin of Hinduism } \\
\text { and Budhism in Indonesia }\end{array}$ & $\begin{array}{lr}\text { - } & \text { Teacher to } \\
\text { students } & \\
\text { - } & \text { Students' } \\
\text { response: } & \text { sending } \\
\text { their observation }\end{array}$ \\
\hline $\begin{array}{l}\text { While } \\
\text { activity }\end{array}$ & Reading a teks for 10 minutes & Focus: reading a text & $\begin{array}{ll}\text { - } & \text { Teacher to } \\
\text { students } & \\
\text { - } & \text { Students' } \\
\text { response: } & \text { reading a } \\
\text { text } & \end{array}$ \\
\hline
\end{tabular}




\begin{tabular}{|c|c|c|c|c|}
\hline & $\begin{array}{l}\text { Creating a mind map of the advent of } \\
\text { Hinduism and Budhism in Indonesia } \\
\text { and sending the results in } 15 \text { minutes }\end{array}$ & - & Focus & $\begin{array}{l}\text { - Teacher to } \\
\text { students } \\
\text { - } \quad \text { Students' } \\
\text { response: } \\
\text { creating a mind } \\
\text { map }\end{array}$ \\
\hline \multirow[t]{3}{*}{$\begin{array}{l}\text { Post } \\
\text { activity }\end{array}$} & Reviewing the lesson & - & Focus & $\begin{array}{l}\text { - Teacher to } \\
\text { students } \\
\text { - Students' } \\
\text { response: } \\
\text { unidentifiable }\end{array}$ \\
\hline & $\begin{array}{l}\text { Mentioning the topic in the next lesson } \\
\text { (Hinduims and Budhism Kingdoms) }\end{array}$ & - & Preparing & $\begin{array}{l}\text { - } \quad \text { Teacher to } \\
\text { students } \\
\text { - } \quad \text { Students' } \\
\text { response: reading the } \\
\text { chat }\end{array}$ \\
\hline & Saying goodbye & - & Parting & $\begin{array}{lr}\text { - } & \text { Teacher to } \\
\text { studets } & \\
\text { - } & \text { Students' } \\
\text { response: } & \text { saying } \\
\text { goodbye } & \end{array}$ \\
\hline
\end{tabular}

